\title{
Effects of some heavy metals on oats in pot experiments with three different soil types.
}

\author{
ASBJøRn SORTEBERG \\ Department of Soil Fertility and Management, Agricultural University of \\ Norway, 1432 As-NLH, Norway
}

\begin{abstract}
An account is given of two pot experiments, of which one has included all combinations of 5 heavy metals (cadmium, cobalt, lead, mercury and nickel), 3 rates of each metal, 2 rates of lime, and 3 types of soil (clay soil, peat soil and sandy soil). The experiment has run for 4 years (1973-1976). Two parallels have been used for each treatment. A third parallel without crop has been used for soil sampling only. The second experiment has run for 3 years (1974-1976), and has included the same soil types and lime rates, but only cadmium and mercury of the metals. The crop grown in all years has been oats.

$250 \mathrm{mg} /$ pot of all metals except lead have had a distinct yield reducing effect. In the case of mercury, the reducing effect ceases from the third year. It decreases gradually after nickel throughout the experimental period, but not after cadmium and cobalt. Heavy liming ( $\mathrm{pH} 6-7$ ) has almost eliminated the yield reduction after nickel, and has considerably reduced it after cobalt.

The contents of cadmium, nickel, cobalt, and mercury in the yield have been multiplied with the application of $250 \mathrm{mg} /$ pot of the metals mentioned. Application of even $0.5 \mathrm{mg} /$ pot of cadmium resulted in a distinct increase of content both in grain and straw. 0.5 and $5 \mathrm{mg}$ mercury, however, had only slight effect. The content of the metals decreased throughout the experimental period. The effect of mercury in the fourth year has been minimal, even after the highest application rate. Lead application led to only moderate increase in the content of the yield.

Roughly $45-55$ percent of the added rates of cadmium, nickel and cobalt, as a mean value for the soil series, has been recovered as AL-soluble at light liming with $\mathrm{pH}$ approximately 5. Heavy liming has reduced the uptake by $3-7$ percent for cadmium, by $16-20$ percent for nickel, and by $22-24$ percent for cobalt. Generally, the amounts of AL-soluble metal in soils have decreased in the order: series peat $>$ sand $>$ clay.
\end{abstract}

\section{Introduction}

An account has been given in a previous publication (SORTEBERG 1974) of a pot experiment in 1973 with heavy metals in oats. The experiment included three types of soil (clay soil, peat soil and sandy soil), two rates of lime, five heavy metals (cadmium, cobalt, lead, mercury and nickel), and three rates of each metal $(0,50$, and $250 \mathrm{mg} /$ pot of five litres) applied in the form of chlorides. Each series has included two parallels. An additional 
parallel without plants has been conducted for each series with the purpose of providing soil samples.

The report presents the results from the subsequent years, 1974-76, of the same experiment. 1973 yields are also included, as well as a supplementary experiment (Exp. 74) with cadmium and mercury at $0,0.5$ and $5 \mathrm{mg} /$ pot and the same soil types and lime rates as before. The crop throughout the experiments has been oats.

\section{Crop yields}

Exp. 73

Table 1 shows relative yields of sum grain + straw pertaining to the highest metal rate. Neither yielded crops nor diagnostic signs observed hroughout the growth season indicated that the lowest rate of any metal in question had notably influenced the size of the yield. Yield figures for those rates have therefore been excluded. As each treatment has had only two parallels, the yield results have not been subjected to statistical analysis. However, for most of the treatments there has only been a slight difference in yield between the two parallels.

As a supplement to the yield figures in Table 1, the following observations made during the growth season concerning the effects of the highest metal application have been noteworthy:

Table 1. Exp. 73. Oats, relative yield of dry matter (grain + straw) for $250 \mathrm{mg}$ metal per 5 litre pot.

Without metal $=$ 100. L.1. $=$ Light liming. H.1. = Heavy liming.

Series I = Clay soil. Series V $=$ Peat soil. Series VI $=$ Sandy soil.

\begin{tabular}{|c|c|c|c|c|c|c|c|c|c|c|c|}
\hline \multirow{2}{*}{$\begin{array}{l}\text { Heavy } \\
\text { metals }\end{array}$} & \multirow{2}{*}{$\begin{array}{c}\text { Soil } \\
\text { series }\end{array}$} & \multicolumn{2}{|c|}{1973} & \multicolumn{2}{|c|}{1974} & \multicolumn{2}{|c|}{1975} & \multicolumn{2}{|c|}{1976} & \multicolumn{2}{|c|}{ Means } \\
\hline & & L.1. & H.1. & L.1. & H.1. & L.1. & H.1. & L.1. & H.1. & L.1. & H.1. \\
\hline \multirow{3}{*}{$\mathrm{Cd}$} & I & 96 & 89 & 84 & 94 & 92 & 96 & 66 & 78 & 84 & 89 \\
\hline & V & 84 & 83 & 97 & 88 & 82 & 30 & 73 & 104 & 84 & 76 \\
\hline & VI & 97 & 102 & 91 & 97 & 97 & 69 & 78 & 62 & 91 & 83 \\
\hline \multirow{3}{*}{$\mathrm{Ni}$} & I & 41 & 100 & 51 & 103 & 55 & 98 & 78 & 97 & 56 & 99 \\
\hline & V & 27 & 86 & 48 & 103 & 88 & 98 & 81 & 115 & 61 & 101 \\
\hline & VI & 37 & 107 & 58 & 101 & 77 & 82 & 81 & 98 & 63 & 97 \\
\hline \multirow{3}{*}{$\mathrm{Hg}$} & I & 78 & 95 & 114 & 120 & 109 & 102 & 101 & 99 & 101 & 104 \\
\hline & V & 79 & 70 & 116 & 106 & 101 & 103 & 94 & 95 & 98 & 94 \\
\hline & VI & 6 & 6 & 0 & 114 & 134 & 95 & 98 & 93 & 59 & 77 \\
\hline \multirow{3}{*}{$\mathrm{Pb}$} & I & 99 & 98 & 115 & 104 & 98 & 100 & 97 & 92 & 102 & 99 \\
\hline & V & 101 & 101 & 113 & 101 & 103 & 106 & 91 & 123 & 102 & 108 \\
\hline & VI & 103 & 104 & 98 & 102 & 93 & 90 & 98 & 96 & 98 & 98 \\
\hline \multirow{3}{*}{ Co } & I & 65 & 77 & 70 & 100 & 64 & 95 & 86 & 94 & 71 & 91 \\
\hline & V & 82 & 87 & 93 & 92 & 78 & 100 & 68 & 94 & 80 & 93 \\
\hline & VI & 85 & 105 & 90 & 106 & 72 & 101 & 69 & 96 & 79 & 102 \\
\hline
\end{tabular}


Cd.

Obvious growth retardation in all treatments, most pronounced at low lime rate. Ripening nearly a week delayed. In 1975 and 1976 evident Mndeficiency at highest lime rate, causing reduced growth.

$\mathrm{Ni}$.

Severly reduced growth at low lime rate. Only slight effect at highest lime rate. Specific symptoms of Ni deficiency observed in all soil series, probably also induced iron deficiency. Ripening delayed from a few days to three weeks. Moderate Mn deficiency in 1975 at heavy lime application.

$\mathrm{Hg}$.

In the sandy soil series (Series I) definite crop failure occurred at both lime levels in 1973 and at lowest lime rate in 1974. Normal development in 1975 and 1976. The high yield at low lime rate in 1975 must be regarded against the background of the considerably reduced nutrition uptake during the two preceding years.

$\mathrm{Pb}$.

Nothing abnormal in any year, except for a moderate Mn dificiency in 1975 and 1976 at highest lime rate.

Co.

Reduced growth in all treatments, particularly at low lime rate. Series V, low lime rate, showed interveinal chlorosis, probably caused by induced iron deficiency. Partly delayed ripening.

Relative yields have been calculated throughout the experimental period for the highest rate of cadmium and nickel at low lime rates and for cobalt at both lime rates. Cadmium at high lime rate has been eliminated because of severe manganese deficiency during the third and fourth years. The presentation below shows mean values (in percent) for all three soil series compared to no heavy metal applied:

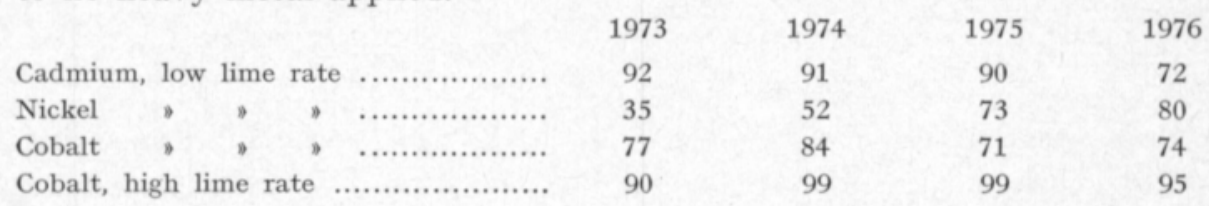

The detrimental effect of heavy nickel application has clearly decreased throughout the experimental period. The figures for cadmium and cobalt showed no such trend. It is difficult to determine whether the final year's increased yield reduction for cadmium is accidental.

Exp. 74

The low rates of cadmium and mercury applied have not influenced the crop yield, and the figures concerned are not reported. 


\section{Heavy metals in the crops}

The content of all heavy metals concerned has been determined in crop from the control pots. Apart from the control, the chemical analyses comprised nothing but the single metal applied. The chemical analyses have been carried out by two laboratories (laboratory $\mathrm{A}^{1}$ and laboratory $\mathrm{B}^{2}$ ).

The analytical methods used have been described previously (SORTEBERG 1974). Laboratory $A$ is responsible for the results of Exp. 73 in 1973 and 1975, and for Exp. 74 in 1975. Laboratory B is responsible for all the other crop analyses.

Table 2 shows the cadmium, nickel, lead and cobalt contents in grain and straw for Exp. 73. From a relatively large recorded material only the mean values of soil and year have been given. The statistical material shows wide variation.

Cd.

Without application, the cadmium content is somewhat higher in straw than in grains. Increasing cadmium application leads to a heavy increase, especially in straw. After application the cadmium content in straw is appreciably higher in the peat soil series (Series V) than in the mineral soil ones (I and VI). The difference is less pronounced in grains, but probably real, as it appears in practically every single year. The content from the untreated pots is highest in Series VI for all comparisons. The cadmium content is clearly reduced both in grains and in straw after heavy liming.

After application, the cadmium content decreases through the experimental period in every case up to the third year.

For some reason, hitherto unknown, the cadmium content in straw appeared exceptionally low in the fourth year. However, since cadmium analyses from straw in the fifth year do not in any way confirm this finding, the cadmium content in straw for the fourth year has not been included in Table 2 .

The contents from the untreated pots for each respective year suggest that a higher cadmium value has been found, at low levels, by laboratory B than by laboratory A. (Probably because of the balance on the detection units.)

$\mathrm{Ni}$.

The content of the crop rises sharply with increasing application. Par: ticularly in the treatments with nickel application the content proves to be much higher in grains than in straw. This seems to be a characteristic feature of oats among the grain crops, as previously shown by ANDERSSON and Nilsson (1975) and by Sorteberg (1974). At application, the content is higher both in grains and straw in the peat soil series than in the two mineral soil ones, despite the fact that the content after no application is lowest in the peat soil series. Increased liming has reduced the nickel uptake considerably.

1) The Central Institute for Industrial Research, Oslo.

${ }^{2}$ ) Chemical Research Laboratory, Agricultural University of Norway. 
Table 2. Exp. 73, 1973-76. Heavy metals in oats, $\mathrm{mg} / \mathrm{kg}$ dry matter.

\begin{tabular}{|c|c|c|c|c|c|c|c|c|c|c|c|c|c|c|}
\hline \multirow{3}{*}{ 窇 } & \multirow{3}{*}{ હ्र } & \multirow{3}{*}{$\overline{D^{\circ}}$} & \multicolumn{6}{|c|}{ Grain } & \multicolumn{6}{|c|}{ Straw } \\
\hline & & & \multicolumn{2}{|c|}{ Light liming } & \multicolumn{4}{|c|}{$\begin{array}{l}\text { Heavy liming } \\
\text { ed heavy metals, }\end{array}$} & \multicolumn{3}{|c|}{$\begin{array}{l}\text { Light liming } \\
\text { per pot (5 ltr.) }\end{array}$} & \multicolumn{3}{|c|}{ Heavy liming } \\
\hline & & & 0 & 50 & 250 & 0 & 50 & 250 & 0 & 50 & 250 & 0 & 50 & 250 \\
\hline \multirow{8}{*}{$\mathrm{Cd}$} & & I & 0,09 & 5,4 & 9,9 & 0,07 & 2,3 & 5,4 & 0,20 & 9,3 & 31 & 0,17 & 2,5 & 9,1 \\
\hline & $* * *$ & V & 0,07 & 8,3 & 16 & 0,03 & 4,9 & 8,4 & 0,15 & 30 & 93 & 0,15 & 17 & 43 \\
\hline & & VI & 0,20 & 6,3 & 14 & 0,11 & 2,4 & 6,6 & 0,22 & 12 & 55 & 0,19 & 3,4 & 13 \\
\hline & & & & & & & & & & & & & & \\
\hline & 1. & & 0,11 & 7,9 & 18 & 0,07 & 3,9 & 9,0 & 0,18 & 25 & 94 & 0,14 & 14 & 42 \\
\hline & 2. & & 0,19 & 7,4 & 13 & 0,11 & 3,4 & 6,7 & 0,29 & 17 & 52 & 0,23 & 5,2 & 14 \\
\hline & 3. & $* * * * *$ & 0,06 & 4,6 & 9,0 & 0,03 & 2,3 & 4,8 & 0,11 & 8,8 & 34 & 0,15 & 3,8 & 9,0 \\
\hline & 4. & & 0,15 & 2,8 & 6,0 & 0,12 & 2,3 & 4,9 & & & & & & \\
\hline
\end{tabular}

$\begin{array}{llllrlrlllllll} & \text { I } & 3,3 & 20 & 59 & 0,98 & 3,4 & 11 & 0,66 & 2,7 & 24 & 0,78 & 0,64 & 1,2 \\ \text { V } & 0,97 & 63 & 110 & 0,25 & 30 & 72 & 0,67 & 19 & 69 & 0,54 & 6,6 & 23 \\ & \text { VI } & 1,3 & 24 & 89 & 0,71 & 8,2 & 33 & 0,80^{*} & 4,6 & 61 & 0,80^{*} & 0,65^{*} & 7,5\end{array}$

$\mathrm{Ni}$

\begin{tabular}{|c|c|c|c|c|c|c|c|c|c|c|c|c|c|}
\hline 1. & & 1,4 & 42 & 110 & 0,73 & 19 & 45 & $0,22 * *$ & 12 & 80 & $0,20^{* *}$ & $5,5^{* *}$ & 18 \\
\hline 2. & & 2,6 & 42 & 92 & 1,0 & 16 & 47 & 1,3 & 10 & 61 & 1,6 & 2,9 & 15 \\
\hline 3. & $* * * * *$ & 1,6 & 34 & 74 & 0,29 & 12 & 35 & 0,33 & 7,6 & 40 & 0,20 & 1,6 & 10 \\
\hline 4. & & 1,6 & 25 & 58 & 0,54 & 7,2 & 27 & 0,77 & 4,9 & 23 & 0,70 & 2,1 & 7,5 \\
\hline
\end{tabular}

$\begin{array}{llllllllllllll} & \text { I } & 0,21 & 0,33 & 0,39 & 0,34 & 0,31 & 0,28 & 2,1 & 2,1 & 2,8 & 2,1 & 2,3 & 2,5 \\ \text { V } & 0,30 & 0,52 & 2,6 & 0,26 & 0,33 & 0,58 & 1,3 & 4,3 & 15 & 1,5 & 2,0 & 5,0 \\ & \text { VI } & 0,27 & 0,30 & 0,51 & 0,23 & 0,34 & 0,43 & 1,7 & 21 & 2,9 & 1,8 & 2,0 & 2,2\end{array}$

$\mathrm{Pb}$

\begin{tabular}{lllllllllllll} 
1. & 0,23 & 0,37 & 0,87 & 0,30 & 0,27 & 0,50 & 1,5 & 2,7 & 6,5 & 1,7 & 2,2 & 4,5 \\
2. & 0,37 & 0,68 & 1,8 & 0,46 & 0,63 & 0,82 & 2,5 & 3,8 & 7,8 & 2,2 & 2,6 & 3,6 \\
3. ***** & 0,18 & 0,29 & 1,2 & 0,17 & 0,12 & 0,14 & 1,6 & 2,5 & 6,8 & 2,0 & 1,7 & 2,3 \\
4. & 0,24 & 0,36 & 0,76 & 0,17 & 0,28 & 0,26 & 1,2 & 2,2 & 5,7 & 1,3 & 2,1 & 2,6 \\
\hline
\end{tabular}

$\begin{array}{llllclllllllll} & \text { I } & 0,6 & 1,7 & 7,1 & 0,6 & 0,42 & 1,4 & 0,46 & 5,5 & 24 & 0,50 & 0,92 & 2,8 \\ \text { V } & 0,6 & 3,9 & 17 & 0,3 & 1,9 & 7,7 & 0,32 & 17 & 71 & 0,37 & 8,7 & 32 \\ & \text { VI } & 0,6 & 1,4 & 9,4 & 0,6 & 0,58 & 1,8 & 0,52^{*} & 6,2 & 33 & 0,50^{*} & 1,9 & 6,4\end{array}$

\begin{tabular}{|c|c|c|c|c|c|c|c|c|c|c|c|c|c|}
\hline 1. & & $<0,10^{* *}$ & 3,5 & 17 & $<0,1^{* *}$ & 1,7 & 5,8 & $0,14 * *$ & 18 & 79 & $<0,1^{* *}$ & 8,1 & 27 \\
\hline 2. & & 0,6 & 2,4 & 10 & 0,6 & 0,97 & 3,1 & 0,63 & 9,4 & 42 & 0,84 & 3,8 & 13 \\
\hline 3. & $* * * * *$ & 0,1 & 1,8 & 8,7 & 0,1 & 0,50 & 2,4 & 0,26 & 5,8 & 25 & 0,2 & 1,7 & 7 , \\
\hline 4. & & 0,28 & 1,7 & 8,0 & 0,3 & 0,64 & 3,3 & 0,57 & 4,1 & 20 & 0,59 & 1,8 & 7,5 \\
\hline
\end{tabular}

* 1. year omitted

** Series VI omitted

*** Mean 1.-3. year

**** Mean 1.-4. year

***** Mean all series 
Table 3. Exp. 73. Soil series III, 1975. Ni content in different parts of plants, mg/kg dry matter.

\begin{tabular}{rcccccc}
\hline & \multicolumn{2}{c}{ Kerne } & \multicolumn{2}{c}{ G lum e s } & \multicolumn{2}{c}{ S t r a w } \\
$\begin{array}{c}\text { Added Ni } \\
\text { mg/pot }\end{array}$ & $\begin{array}{c}\text { Light } \\
\text { liming }\end{array}$ & $\begin{array}{l}\text { Heavy } \\
\text { liming }\end{array}$ & $\begin{array}{l}\text { Light } \\
\text { liming }\end{array}$ & $\begin{array}{l}\text { Heavy } \\
\text { liming }\end{array}$ & $\begin{array}{l}\text { Light } \\
\text { liming }\end{array}$ & $\begin{array}{l}\text { Heavy } \\
\text { liming }\end{array}$ \\
\hline 0 & 4.2 & 0.87 & 0.65 & 0.43 & 0.85 & 0.64 \\
50 & 34 & 2.7 & 3.9 & 0.65 & 3.4 & 0.63 \\
250 & 96 & 9.9 & 21 & 1.5 & 40 & 1.8 \\
\hline
\end{tabular}

The nickel content shows obvious reduction in the course of time after application date.

In order to find out more accurately about the distribution of nickel in the yields, some supplementary analyses have been performed from treatments in Series III, 1975. The soil in this series is a compound of 50 volume percent clay soil and 50 volume percent peat soil. The results from this series have not been considered in the report. The nickel content was determined for these treatments in straw, kernels and glumes (Table 3). At heavy liming the content of the glumes corresponds well with that in straw. At light liming however, the content of the glumes is considerably lower than in the straw at the heaviest nickel application. The high nickel content in the grain of oats cannot, in any case, be explained by high content in the glumes.

$\mathrm{Pb}$.

In the mineral soil series even the highest amount of lead has led to a moderate increase in the crop, the content being approximately doubled at heaviest application. In the peat soil series, however, the content has been multiplied. Liming had little effect on the lead uptake in mineral soils. In the peat soil series the uptake has been strongly reduced, particularly at the highest lead level. The lead content shows several times higher values in straw than in grains with application as well as without.

The lead content in the yield from year to year does not present an explicit pattern. The analysis results may also in this case suggest that the figures from laboratory $B$ range higher than those from laboratory A at low levels.

Co.

The cobalt content in the yield increases considerably at cobalt application. The content of the untreated pots is generally lower in the peat soil series than in the mineral soils, though it increases a great deal more after application. Increased liming has had no effect on the cobalt content of the untreated pots but has reduced the content markedly after cobalt application. In all series with cobalt application, the content decreases notably from the first to the third year of the experiment.

$\mathrm{Hg}$.

The mercury content is presented in Table 4. In and after the second year of the experiment the mercury content, with and without application, 
Table 4. Exp. 73. $\mathrm{Hg}$ in dry matter of oats, $u \mathrm{~g} / \mathrm{kg}$.

\begin{tabular}{|c|c|c|c|c|c|c|c|c|c|c|c|c|c|}
\hline \multirow{3}{*}{$\begin{array}{l}\text { Soil } \\
\text { series }\end{array}$} & \multirow{3}{*}{ Year } & \multicolumn{6}{|c|}{ Grain } & \multicolumn{6}{|c|}{ Straw } \\
\hline & & \multicolumn{3}{|c|}{ Light liming } & \multicolumn{3}{|c|}{$\begin{array}{c}\text { Heavy liming } \\
\text { Added } \mathrm{Hg} \text {, mg per }\end{array}$} & \multicolumn{3}{|c|}{$\begin{array}{l}\text { Light liming } \\
\text { pot (5 ltr.) }\end{array}$} & \multicolumn{3}{|c|}{ Heavy liming } \\
\hline & & 0 & 50 & 250 & 0 & 50 & 250 & 0 & 50 & 250 & 0 & 50 & 250 \\
\hline \multirow[t]{2}{*}{ I } & 1. & 5 & $\mathrm{x}$ & 260 & 8 & 32 & 53 & 32 & 95 & 1300 & 83 & 130 & 1000 \\
\hline & 4. & 10 & 9 & 9 & 10 & 10 & 15 & 22 & 25 & 26 & 20 & 32 & 21 \\
\hline \multirow[t]{2}{*}{ V } & 1. & 45 & 180 & 630 & 43 & 270 & 310 & 110 & 740 & 8600 & 58 & 710 & 8400 \\
\hline & 4. & $<4$ & 9 & 10 & $<4$ & 5 & 9 & 14 & 56 & 30 & 18 & 39 & 28 \\
\hline \multirow[t]{2}{*}{ VI } & 1. & $<20$ & 150 & $\mathrm{xx}$ & 25 & 140 & $\mathrm{xx}$ & 110 & 3400 & 99000 & 26 & 1700 & 39000 \\
\hline & 4. & $<4$ & 8 & 9 & $<4$ & 11 & $<5$ & 21 & 26 & 22 & 24 & 20 & 32 \\
\hline
\end{tabular}

x) Inaccurate result

xx) No yield

has at times been below the detection limits of the laboratories. The table, therefore, only presents the yield contents for the first and the fourth experimental years. An almost total crop failure in the first year at the highest mercury amounts in series VI has of course been strongly contributory to the exceptionally high content in straw this year. It is partly the case also for Series I and V. Even with the slightly reduced yield taken into account, the increase in these two series still appears extremely high for straw at the highest mercury level. In Series VI it is also very high at the lowest level. The mercury content is, particularly after application, notably less in the grains than in the straw. This property has not been influenced by liming. In the fourth experimental year, the effect of the mercury application can still be detected in crop grown in the peat soil, whereas on the mineral soils it no longer had any effect.

Exp. 74

This experiment with cadmium and mercury applications only, has run for a three year period. The contents of these metals in the yield are given in Table 5 .

Cd.

The small rate of $0.5 \mathrm{mg} /$ pot $(0.2 \mathrm{~kg} /$ hectare $)$ has increased the content notably in all soil series, mostly in Series V. At $5 \mathrm{mg} /$ pot the content has increased strongly. The increase in grains shows a falling trend from the first to the third year of the experiment. The figures of the analyses for straw are omitted for the third year for the same reason as those given for the forth experimental year of Exp. 73. Liming has distinctly reduced the cadmium content in grains as well as in straw.

$\mathrm{Hg}$.

The content in grain has for most treatments been too low for determination, and figures representing the content have therefore been excluded from the table. The content in straw shows moderate increase after mercury appli- 
Table 5. Exp. 74, 1974-76. Heavy metals in oats, $\mathrm{mg} / \mathrm{kg}$ dry matter for $\mathrm{Cd}$ and $u g / \mathrm{kg}$ dry matter for $\mathrm{Hg}$.

\begin{tabular}{|c|c|c|c|c|c|c|c|c|c|c|c|c|c|c|}
\hline \multirow{3}{*}{$\begin{array}{l}\text { Heavy } \\
\text { metals }\end{array}$} & \multirow{3}{*}{ Year } & \multirow{3}{*}{$\begin{array}{l}\text { Soil } \\
\text { series }\end{array}$} & \multicolumn{6}{|c|}{ Grain } & \multicolumn{6}{|c|}{ Straw } \\
\hline & & & \multicolumn{3}{|c|}{ Light liming } & \multicolumn{3}{|c|}{$\begin{array}{c}\text { Heavy liming } \\
\text { Added heavy metals, }\end{array}$} & \multicolumn{3}{|c|}{$\begin{array}{c}\text { Light liming } \\
\text { mg per pot (5 ltr.) }\end{array}$} & \multicolumn{3}{|c|}{ Heavy liming } \\
\hline & & & 0 & 0,5 & 5 & 0 & 0,5 & 5 & 0 & 0,5 & 5 & 0 & 0,5 & 5 \\
\hline \multirow{7}{*}{$\mathrm{Cd}$} & \multirow{3}{*}{$\mathbf{x x}$} & I & $<0,05$ & 0,11 & 0,68 & $<0,05$ & 0,07 & 0,40 & 0,09 & 0,18 & 0,64 & $<0,05$ & 0,10 & 0,26 \\
\hline & & V & 0,09 & 0,39 & 2,7 & $<0,05$ & 0,31 & 2,2 & 0,14 & 0,85 & 6,3 & 0,05 & 0,69 & 4,7 \\
\hline & & VI & 0,17 & 0,21 & 1,3 & 0,06 & 0,16 & 0,67 & 0,17 & 0,42 & 1,4 & 0,11 & 0,19 & 0,52 \\
\hline & & & & & & & & & & & & & & \\
\hline & 1. & & 0,12 & 0,32 & 1,8 & 0,06 & 0,26 & 1,3 & 0,10 & 0,47 & 2,6 & 0,08 & 0,39 & 2,0 \\
\hline & 2. & & 0,08 & 0,15 & 1,3 & 0,03 & 0,09 & 0,85 & 0,16 & 0,49 & 2,9 & 0,05 & 0,25 & 1,7 \\
\hline & 3. & & 0,13 & 0,20 & 0,89 & 0,12 & 0,18 & 0,62 & & & & & & \\
\hline \multirow{7}{*}{$\mathrm{Hg}$} & & $I^{x}$ & & & & & & & 21 & 21 & 23 & 26 & 24 & 23 \\
\hline & $\mathbf{x x x}$ & $V^{x}$ & & & & & & & 14 & 25 & 24 & 16 & 25 & 25 \\
\hline & & $V I^{x}$ & & & & & & & 19 & 23 & 32 & 20 & 24 & 36 \\
\hline & & & & & & & & & & & & & & \\
\hline & $1 .^{x}$ & & & & & & & & 26 & 23 & 38 & 27 & 33 & 41 \\
\hline & 2. $x$ & $\operatorname{xxxx}$ & & & & & & & 8 & 23 & 20 & 12 & 18 & 17 \\
\hline & $3 . x$ & & & & & & & & 21 & 23 & 22 & 23 & 21 & 26 \\
\hline
\end{tabular}

x) 37 of 54 grain samples had too low content for $\mathrm{Hg}$ to be determined. Just 2 samples had higher content than $10 u g / k g$ dry matter. xx) Mean 1. and 2. year. xxx) Mean 1-3 year. xxxx) Mean all series.

cation in Series V and VI, though no increase appears in Series I. Increased liming hade no effect on the content. The contents of the control pots are lower in Series V than in Series I and VI, which does not correspond to Exp. 73. At the highest mercury application the content is evidently higher in the first than in the second and third experimental years.

Table 6 shows the uptake of metals by the harvested crop of Exp. 73, in percent of the applied amounts for the period 1973-76. Mercury has not been included in the table, partly because of the severe yield reduction induced by the highest mercury application, and partly because the mercury uptake declined considerably already from the second year of the experiment.

The uptake of all heavy metals reflects, to a large extent, the relative contents in the yields of the respective metals (Table 2) with deviations induced by varying yields from different treatments.

A much higher proportion of all applied metals has been recovered by the crops grown in the peat soil than in the mineral soil series. At lowest application rate, Series V has recovered 23 percent of nickel, 9 percent of cadmium, and 6 percent of cobalt at light liming, whereas only a fraction of these metals has been recovered from the mineral soils. A higher proportion of applied metal amounts is generally recovered from sandy soil than from the clay soil series.

In most comparisons a higher, even a considerably higher percentage of applied metal has been recovered at low than at high application rates. This is to some extent due to yield reduction at high metal application because of the direct detrimental effect of the metal, and partly to an indirect influence (manganese deficiency). 
Table 6. Exp. 73. Uptake of heavy metals in crops for the experimental period 1973-1976, percent of added.

\begin{tabular}{|c|c|c|c|c|c|c|c|c|c|c|c|c|c|}
\hline \multirow{3}{*}{ Metal } & \multirow{3}{*}{$\begin{array}{l}\text { Soil } \\
\text { series }\end{array}$} & \multicolumn{5}{|c|}{ Grain } & \multicolumn{2}{|c|}{ St raw } & \multicolumn{5}{|c|}{ Grain + straw } \\
\hline & & \multicolumn{12}{|c|}{$\begin{array}{l}\text { Light liming Heavy liming Light liming Heavy liming Light liming Heavy liming } \\
\text { Difference added metal - control, mg per pot }\end{array}$} \\
\hline & & $50-0$ & $250-0$ & $50-0$ & $250-0$ & $50-0$ & $250-0$ & $50-0$ & $250-0$ & $50-0$ & $250-0$ & $50-0$ & $250-0$ \\
\hline \multirow{3}{*}{$\mathrm{Cd}$} & I & 1.2 & 0.4 & 0.8 & 0.2 & 1.6 & 0.8 & 0.4 & 0.3 & 2.8 & 1.2 & 1.2 & 0.5 \\
\hline & v & 1.6 & 0.7 & 1.2 & 0.3 & 7.2 & 3.8 & 4.2 & 1.4 & 8.8 & 4.5 & 5.4 & 1.7 \\
\hline & VI & 1.0 & 0.4 & 0.6 & 0.2 & 2.0 & 1.6 & 0.6 & 0.4 & 3.0 & 2.0 & 1.2 & 0.6 \\
\hline \multirow{3}{*}{$\mathrm{Ni}$} & I & 4.0 & 1.4 & 0.6 & 0.5 & 0.6 & 0.5 & 0 & 0 & 4.6 & 1.9 & 0.6 & 0.5 \\
\hline & V & 17.6 & 3.2 & 6.6 & 3.6 & 5.6 & 2.2 & 1.6 & 1.5 & 23.2 & 5.4 & 8.2 & 5.1 \\
\hline & VI & 4.6 & 2.0 & 1.4 & 1.2 & 1.0 & 1.2 & 0 & 0.3 & 5.6 & 3.2 & 1.4 & 1.5 \\
\hline \multirow{3}{*}{$\mathrm{Pb}$} & I & 0.02 & + & 0 & 0 & 0.04 & 0.02 & 0.08 & 0.01 & 0.06 & 0.02 & 0.08 & 0.01 \\
\hline & V & 0.11 & 0.12 & 0.02 & 0.02 & 0.94 & 0.79 & 0.14 & 0.21 & 1.05 & 0.91 & 0.16 & 0.23 \\
\hline & VI & 0.02 & + & 0.02 & 0.02 & 0.06 & 0.04 & 0.02 & 0.02 & 0.08 & 0.04 & 0.04 & 0.04 \\
\hline \multirow{3}{*}{ Co } & I & 0.6 & 0.2 & 0 & 0 & 1.0 & 0.6 & 0.2 & 0.1 & 1.6 & 0.8 & 0.2 & 0.1 \\
\hline & V & 1.0 & 0.8 & 0.4 & 0.3 & 4.8 & 3.0 & 2.6 & 1.5 & 5.8 & 3.8 & 3.0 & 1.8 \\
\hline & VI & 0 & 0.7 & 0 & + & 0 & 1.1 & 0.4 & 0.3 & 0 & 1.8 & 0.4 & 0.3 \\
\hline
\end{tabular}

\section{Soil analyses}

After harvesting soil samples were taken from the pots without plants for chemical analyses with regard to the difefrent metals added. For the first two years of Exp. 73 and the first year of Exp. 74 these pots were stored in identical temperatures and were kept in a moist condition during the growing season like the cropped parallels. During the last two years, however, the uncropped pots were stored in a room with a moderate temperature also in winter time. The intention with this procedure was to save time by speeding those processes in the soil which may exert an influence on the binding or release of heavy metals.

The method of EGNER et al. (1960) with AL-solution has been used for the soil extraction. The analytical work has been carried out by the National Swedish Laboratory for Agricultural Chemistry, Ultuna, Sweden, during the first two years, and by the Laboratory at the Department of Soil Science, Agricultural University of Norway, for the last two years.

The extracted amounts of applied cadmium, nickel, lead and cobalt from soil in Exp. 73 are presented by Figures 1, 2, 3, and 4, respectively; and Table 7 shows the average amounts of extracted cadmium, nickel and cobalt of added metal.

Cd.

In most comparisons, and as an average for every year, slightly more cadmium has been extracted at low than at heavy liming (Figure 1 and Table 7). Some of the figures for extracted metal amounts can not be explained. Thus, the extracted amounts of cadmium seem too low for the first year in Series VI at $50 \mathrm{mg}$ added and in Series I at $250 \mathrm{mg}$. It does, on the other hand, seem 

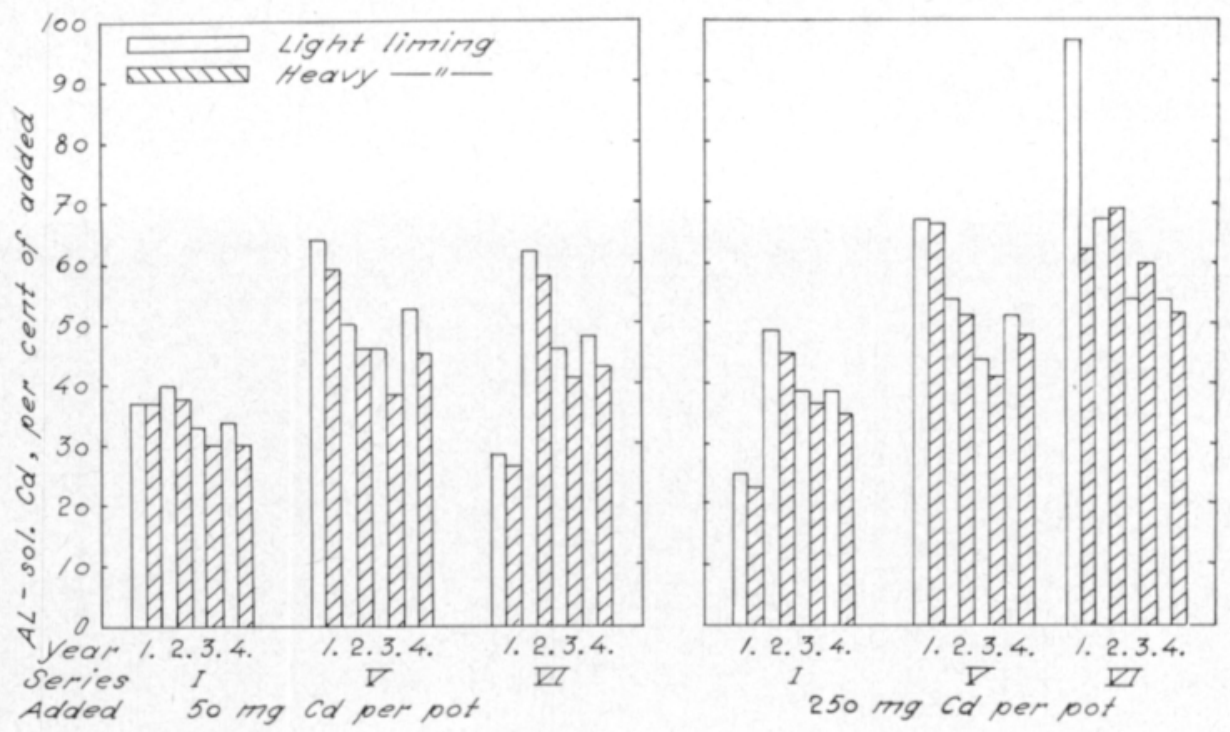

Figure 1. Exp. 73. AL-soluble $\mathrm{Cd}$ in soil samples, percent of added.

too high for the first year at light liming and $250 \mathrm{mg}$ added cadmium in Series VI (Figure 1).

A smaller amount of cadmium has generally been extracted from soil Series I than from Series V and VI. Mean values for rates of cadmium and lime in percent of added, were:

$\begin{array}{ccccc}\text { Soil ser. } & \text { 1. year } & \text { 2. year } & \text { 3. year } & \text { 4. year } \\ \text { I } & 30 & 43 & 35 & 34 \\ \text { V } & 64 & 50 & 42 & 49 \\ \text { VI } & 53 & 64 & 50 & 49\end{array}$

In Series $\mathrm{V}$ the highest amounts of cadmium have been extracted in the first year, while, surprisingly, the extracted amounts have been highest in the second year in Series I and Series VI. However, the extracted amounts throughout the experimental period should be regarded in relation to the cadmium removed by the crop. According to added rates of cadmium and lime in Series V, the crop has removed $\mathbf{1 . 7}-\mathbf{8 . 8}$ percent of the added cadmium, that is on the average $\mathbf{5 . 1}$ percent. For Series I and Series VI the average would be 1.4 and 1.7 , respectively.

Ni.

In most comparisons considerably more nickel has been extracted after light than after heavy liming (Figure 2 and Table 7). Evidently less nickel has also been extracted from Series I than from Series V and VI. As an average for rates of nickel and lime the nickel extracted in percent of added has been:

$\begin{array}{ccccc}\text { Soil ser. } & \text { 1. year } & \text { 2. year } & \text { 3. year } & \text { 4. year } \\ \text { I } & 29 & 25 & 21 & 20 \\ \text { V } & 63 & 57 & 63 & 51 \\ \text { VI } & 43 & 53 & 43 & 40\end{array}$


Table 7. Exp. 73. $\mathrm{Cd}, \mathrm{Ni}$ and $\mathrm{Co}$ in soil samples extracted by Al-solution at light and heavy liming, percent of added. Means of the 3 soil series and the 2 rates of metal.

\begin{tabular}{|c|c|c|c|c|c|c|}
\hline \multirow{2}{*}{ Metal } & \multirow{2}{*}{ Liming } & \multicolumn{4}{|c|}{ Year } & \multirow{2}{*}{ Means } \\
\hline & & 1. & 2. & 3. & 4. & \\
\hline \multirow{3}{*}{$\mathrm{Cd}$} & Light & 53 & 54 & 44 & 46 & 49 \\
\hline & Heavy & 46 & 51 & 41 & 42 & 45 \\
\hline & Light minus heavy & 7 & 3 & 3 & 4 & 4 \\
\hline \multirow{3}{*}{$\mathrm{Ni}$} & Light & 53 & 54 & 52 & 46 & 51 \\
\hline & Heavy & 37 & 36 & 32 & 27 & 33 \\
\hline & Light minus heavy & 16 & 18 & 20 & 19 & 18 \\
\hline \multirow{3}{*}{ Co } & Light & 56 & 50 & 45 & 45 & 49 \\
\hline & Heavy & 34 & 26 & 23 & 22 & 26 \\
\hline & Light minus heavy & 22 & 24 & 22 & 23 & 23 \\
\hline
\end{tabular}

The lowest amount of nickel has been extracted in Series I and the highest in Series V. The extracted amount has decreased throughout the experimental period in Series I. Series V and VI show no similar trend.

The percentage of added nickel recovered in crops was on the average 1.9 percent for Series I, 10.0 percent for Series V, and 2.9 percent for Series VI. $\mathrm{Pb}$.

The extracted amounts of lead are considerably smaller than those of cadmium and nickel (Fig. 3). Most figures range between 5 and 15 percent of the applied amount. After application of $50 \mathrm{mg}$ lead the analysis from Series VI during the first two years shoved either no increase, or, in some cases, unreasonable high increases in lead content. No figures are given for lead for those two years.

Figure 2. Exp. 73. AL-soluble $\mathrm{Ni}$ in soil samples, percent of added.

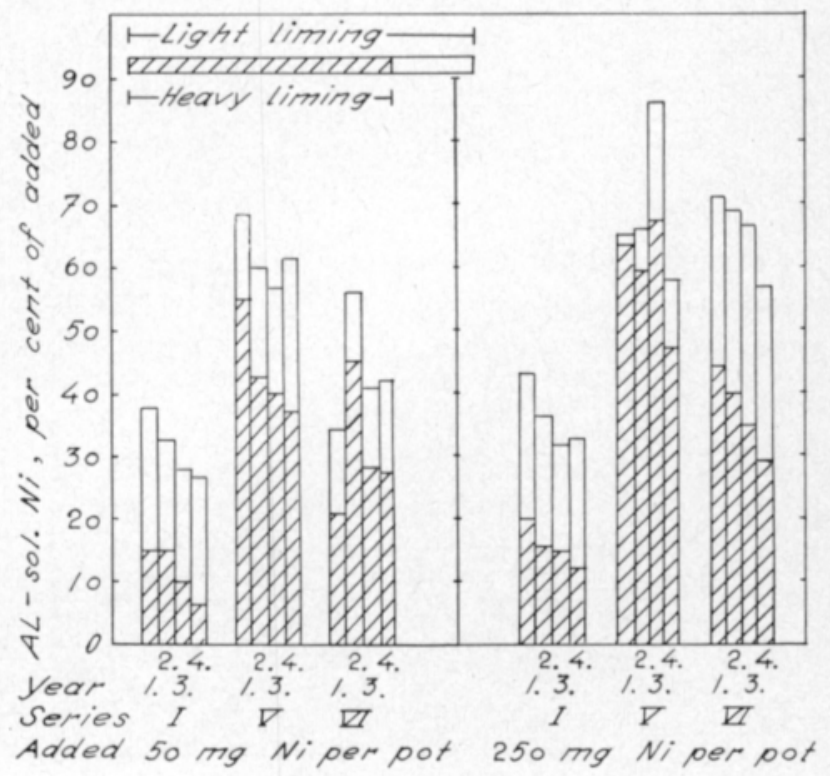



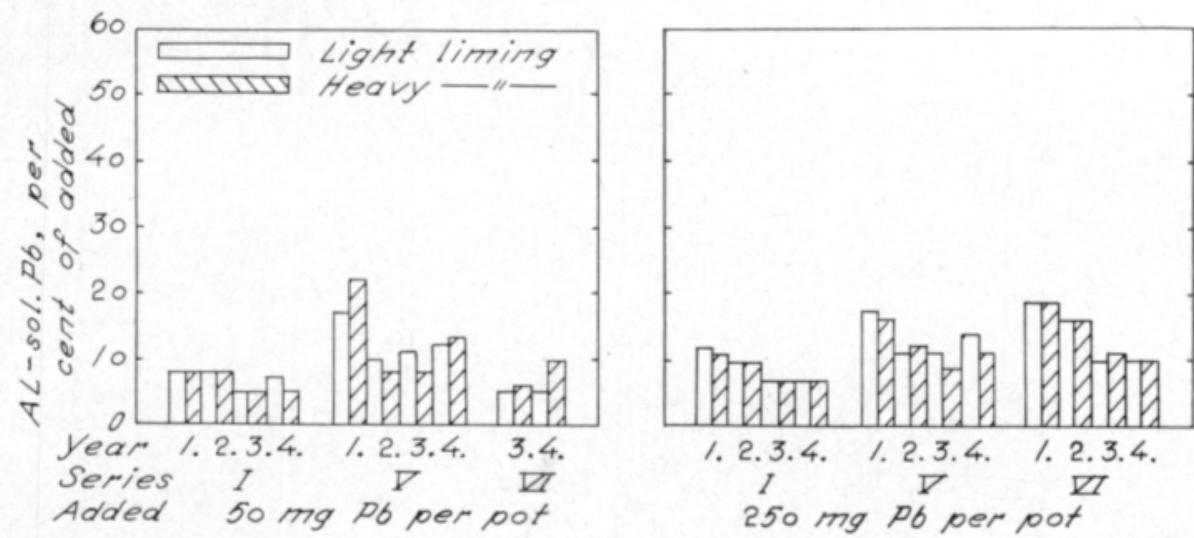

Figure 3. Exp. 73. AL-soluble $\mathrm{Pb}$ in soil samples, percent of added.

Heavier liming has had no influence on the amount of extracted lead. Somewhat more lead has been extracted from Series V in the first year than in the subsequent ones. Figure 3 indicates the reduced amount extracted from the two mineral soil series also beyond the second year of the experiment.

Co.

The extracted amount shows great variation with soil and lime rates (Figure 4). Except for the first year, double the amount of cobalt has been extracted after light liming compared to heavy liming (Table 7) as a mean of soil and amounts applied. Heavier liming has, however, reduced extracted cobalt amounts considerably more from Series I and VI than from Series V (Figure 4 and Table 8). At light liming, the extracted amount is much smaller for Series I than for Series V and VI, at high liming it is much smaller also for Series VI.

Mean values extracted for added rates of cobalt and lime in percent of added were as follows:

$\begin{array}{ccccc}\text { Soil ser. } & \text { 1. year } & \text { 2. year } & \text { 3. year } & \text { 4. year } \\ \text { I } & 25 & 21 & 15 & 17 \\ \text { V } & 73 & 55 & 56 & 54 \\ \text { VI } & 39 & 37 & 30 & 30\end{array}$

Series I and Series VI show a decreasing trend of extracted cobalt throughout the experimental period, and in Series $\mathrm{V}$ the extracted amount is highest in the first year.

Table 8. Exp. 73. Co in soil samples extracted by AL-solution, percent of added. Means of 2 rates of metal and 4 experimental years.

\begin{tabular}{lccc}
\hline Soil series & Light liming & Heavy liming \\
\hline & & & \\
I & 30 & 9 \\
V & 65 & 53 \\
VI & 52 & 16 \\
\hline
\end{tabular}


Figure 4. Exp. 73. AL-soluble Co in soil samples, pcrceent of added.

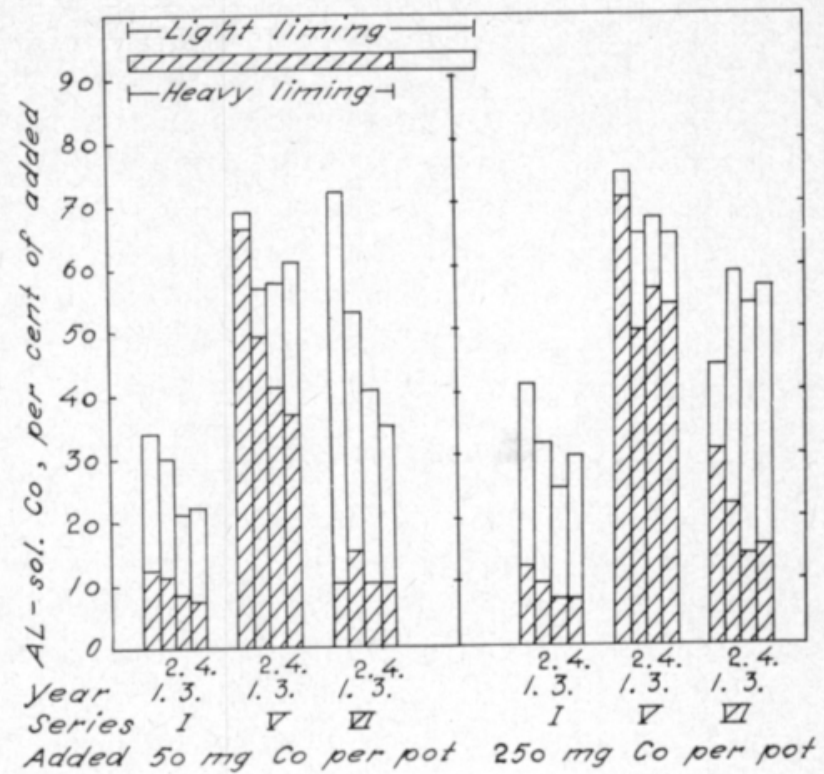

The mean value of recovered cobolt in crop in percent of added has for Series $\mathrm{V}$ been 3.6. For Series I and VI the recovering has been less than 1 percent.

$\mathrm{Hg}$.

Only $2-3$ percent of the applied mercury was extracted the first year. The extracted amount for the second year was less than 1 percent in all soil samples. This metal has therefore not been determined in the last years.

\section{Exp. 74 .}

The analysis figures for cadmium extracted (not shown in tables or figures) varied and apperently there are casual fluctuations from year to year. No more AL-soluble cadmium was recovered after 5 than after $0.5 \mathrm{~g}$, either in the entire experimental period, or in the third years. The effect of liming has been slight also in this experiment. The mean extracted amount for all parallels and years is 46 percent of the applied cadmium amount, i.e. approximately the same as in Exp. 73, considering the much higher rates of cadmium in this experiment. The quantity of extracted cadmium was smaller with regard to soil from Series I (31 percent) than from Series V (53 percent) and VI (55 percent) in Exp. 74.

\section{Discussion}

Lead distinguishes itself among all heavy metals included in this experiment by having no influence on the size of the yield. The lead uptake in the plants has increased notably, though not strongly, with increased lead application. Liming has retarded the lead uptake in the peat soil series, but de- 
pending on lead application. Without lead application, liming had no effect on the lead content. At $50 \mathrm{mg}$ lead per pot, liming has reduced the content some what, and at the highest application, the reduction was substantial. Cox and Rarns (1972) grew 5 species in pot experiments on two lead contaminated soils and with three rates of lime ( $\mathrm{pH}$ interval approximately $5-7$ ). Liming induced decreased lead content in all plants. The reduction increased in most cases with the increasing content in the plants. ANDERsson and Nilsson (1975), however, found only a slight effect on the lead content from increasing lime rates $(\mathrm{pH} 4.8,6.0$ and 7.2) on spring wheat grown in a pot experiment. Varying lime rates were also of insignificant importance for extracted lead amounts at $1 \mathrm{M} \mathrm{NH}_{4} \mathrm{Ac}$ from soil samples.

The relatively moderate increase of the lead content in oats in the present experiment compared to that of the remaining heavy metals, corresponds to the moderate amount of lead found as AL-soluble in the soil. Since liming has been shown to have no influence on the amount of AL-soluble lead, the varying lead content in the plants after different lime rates may be of physiological nature rather than an effect on the Al-solubility of lead in soil.

Cadmium, nickel, mercury, and cobalt have all led to more or less reduced yields, at least at the heaviest applications. Mercury distinguishes itself here by reducing the yield severely in the first and, partly, in the second year, whereas there was no effect as from the third year on.

The mercury content in the yield has declined strongly from the first to the fourth experimental year (Table 4). This is also so for treatments where mercury had little or no effect on the yield quantity. In Series I, at the highest mercury application, the yield is only reduced by $5-22$ percent in the first year (Table 1). The mercury content is, however, roughly $40-50$ times higher at light liming, and 7-12 times higher at heavy liming than in the control pots. Series V shows an almost identical picture. In Series VI there appears a relatively corresponding increase in the content at the lowest amount of mercury, without simultaneous yield reduction. In the fourth year, however, all soil series show little or no increase of mercury content in the crop after mercury application.

Subsequent to the first year's harvest, the heavy metal content in the soil was also determined by $2 \mathrm{M} \mathrm{HCl}$ extraction. The extracted amounts fluctuate. Partly more, partly less than the amount applied was recovered. With regard to mercury, the $\mathrm{HCl}$ soluble fraction has also been determined after the fourth year in the pots subject to light liming. The recovered amounts of the applied metal are presented in Table 9. The figures for recovered mercury do not indicate any notable decrease in clay and peat soils. The case is totally different in sandy soil. Even in the first year, some of the mercury has probably disappeared or at least been insoluble in $2 \mathrm{M} \mathrm{HCl}$ at the highest application rate $(250 \mathrm{mg})$, and after the fourth experimental year, the extracted amount is less than one fifth of the applied amount. However, the heavily reduced amounts in $\mathrm{HCl}$ soluble mercury cannot alone explain the normal yields in the third and the fourth years after the heaviest mercury application. Table 4 thus, shows that the mercury content in the plants after the fourth year is much less at the highest application $(250 \mathrm{mg})$ than for $50 \mathrm{mg}$ in 
Table 9. Exp. 73. $\mathrm{Hg}$ soluble in $2 \mathrm{M} \mathrm{HCl}$, percent of added at low liming.

\begin{tabular}{|c|c|c|c|c|}
\hline \multirow[t]{2}{*}{ Soil series } & \multicolumn{4}{|c|}{ 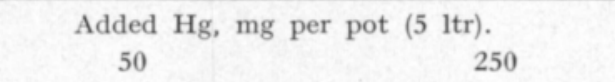 } \\
\hline & 1973 & 1976 & 1973 & 1976 \\
\hline I & 92 & 92 & 69 & 90 \\
\hline V & 81 & 108 & 91 & 76 \\
\hline VI & 115 & 49 & 36 & 18 \\
\hline
\end{tabular}

the first year. The availability of the remaining amount seems also to have been severely reduced during the experimental period.

Cadmium, nickel and cobalt present several common features. All of them have at highest amounts applied combined with low liming, led to retarded growth and/or reduced yield. The yield reduction has been pronouncedly high for nickel. Heavy liming has, nevertheless, practically neutralized the detrimental effect of this metal. Heavier liming has been less effective in eliminating the detrimental effect of cobalt, and least effective against cadmium. The ability of lime to reduce the metal uptake in oats has been higher for nickel and cobalt than for cadmium.

In the case of cobalt, reduced content in the yield corresponds relatively well with the reduced AL-soluble amount in the soil throughout the ecxperimental period. Reduction of the nickel content in the yield does not show the same good correlation to the extracted amount from the soil, and the reduction of cadmium in the yield shows only for one of the series some correspondence to the soluble cadmium content in soil.

ANDERSSON and Nilsson (1975) found in pot experiments great reduction in the cobalt, nickel and cadmium contents at increased liming in spring wheat and rape $(\mathrm{pH} 4.8,6.0,7.2)$, although they found no deviation in the

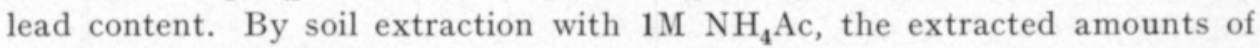
nickel and cobalt declined rapidly with rising $\mathrm{pH}$, while variyng $\mathrm{pH}$ values had little or no effect at all on cadmium and lead. The same authors carried out another investigation in which extractions of various strengths were used for cadmium (1974). In their report they claim that highly acid solutions fail to provide information of the solubility of cadmium at different $\mathrm{pH}$ levels. COPPENET et al. (1972) investigated the cobalt content in Italian rye grass (Lolium italicum). He found it reduced by a rising $\mathrm{pH}$ after lime fertilizer application, whereas the acid ammonium nitrate increased the cobalt content. Concerning cobalt, it has for a long time been known that gras grown on soil with a high $\mathrm{pH}$ generally has a lower cobalt content than grass grown on more acid soil.

A comprehensive literature exists on the cadmium content in plants with regard to different $\mathrm{pH}$. In addition, the solubility of the metal in soil has often been subject of investigation. JoHN and VAN LAERHOVEN (1972) found greatly reduced cadmium contents in lettuce and oats grown in pots after very heavy liming. JoHN (1976) also found in his recent investigations that the relative cadmium uptake and total content in the plants mentioned above were notably less at $\mathrm{pH} 8$ than at $\mathrm{pH} 5$. 
LinNman et al. (1973) found a distinctly reduced cadmium uptake at increasing $\mathrm{pH}$ in the soil within a $\mathrm{pH}$ interval of approximately 5-7 when growing wheat in a pot experiment, whereas TAKIJIMA et al. (1973) found a negative correlation between the cadmium content in rice and the $\mathrm{pH}$ of the soil and the amount of exchangeable $\mathrm{Ca}$.

Williams and David (1976) grew subterranean clover in a pot experiment with red podzolic soil. With the adding of $\mathrm{CaSO}_{4} .2 \mathrm{H}_{2} \mathrm{O}, \mathrm{CaCO}_{3}$ or $\mathrm{MgCO}_{3}$ the soil got a pH-interval ranging form 5.1 to 6.8 . The yield was not affected by any treatment. The cadmium content in plants was almost reduced to one fourth from the lowest to the highest pH. Mille et al. (1976) investigated in pot experiments with 9 different soils the effect of various soil factors on the yield and cadmium uptake in soybeans. They found that the soil cation exchange capacity and the $\mathrm{pH}$ was important for the cadmium accumulation in plants, with a decreasing cadmium uptake at rising values for both factors.

IvaI et al. (1975) obtained somewhat diverging results when growing corn in a water culture experiment where both cadmium and calcium applications as well as the $\mathrm{pH}$ varied. Calcium retarded the cadmium uptake, whereas the cadmium content in the plants remained unchanged in the $\mathrm{pH}$ interval $4-6$. Yield reduction appeared when the cadmium content rose to $20 \mathrm{ppm}$ of the dry matter.

JAnsson (1975) grew spring wheat in pots with and without lime, at $\mathrm{pH}$ 5.3 and 7.0, respectively, with or without a cadmium application. A relatively high cadmium application led to severe yield reduction and a very high cadmium content, particularly without lime. Without cadmium application, however, the cadmium content was substantially higher with lime than without it.

The present experiments indicate that the content of some heavy metals in plants produced on uncontaminated sphagnum peat soil may be low. However, this soil type may also prove sensitive in increasing the metal content should contaminated substances be added.

Acknowledgements. The author wishes to thank the City Council of Oslo for its finaneial support by in paying for all the chemical analyses of heavy metals in crop and soil. Thanks should also be given to the National Agricultural Chemistry Laboratory of Sweden, The Central Institute for Industrial Research, Oslo, the Chemical Research Laboratory and the Laboratory at the Department of Soil Science, Agricultural University of Norway, for the heavy metals determination of a large number of soil and yield samples.

\section{REFERENCES}

Andersson, A. \& Nilsson, K. O. 1974. Influence of lime and soil pH on Cd availability to plants. Ambio 3: 198-200.

— \& Nilsson, K. O. 1975. Effekter på tungmetallhalterna i mark och växt ved tillførsel av røtslam som växtnäringskälla och jordförbättringsmedel. Rapp. 96. Avd. växtnäringslära, Lantbr.högsk., Uppsala.

Coppenet, M., More, E., Le Corre, L. \& Le Mao, M. 1972. Variations de la teneur en cobalt des ray-grass etude de techniques d' enrichissement. Ann. Agron. 23(2): 165-196. 
Cox, W. J. \& Rains, D. W. 1972. Effect of lime on lead uptake by five plant species. J. Environ. Qual. 1, 2: 167-169.

Egner, H., Riem, H. \& Domingo, W. R. 1960. Untersuchungen über die chemische Bodenanalyse als Grundlage für die Beurteilung des Nährstoffzustandes der Böden. II. Chemische Extractionsmethoden zur Phosphor- und Kaliumbestimmung. Kungl. Lantbr.høgsk. Ann. 26: 199-215.

Ivai, I., Hara, T. \& Sonoda, Y. 1975. Factors affecting cadmium uptake by the corn plant. Soil Sci. Plant Nutr. 21(1): 37-46.

JANsson, S. L., 1975. Kadmium i växtnäringsbalansen. Seminar om tungmetaller, sirkulasjon i jordbruket, 24-31. NJF Seksjon I.

Jонм, M. K., 1976. Interrelationships between plant cadmium and uptake of some other elements from culture solutions by oats and lettuce. Environ. Pollut. (11) 2: 85-95.

- \& VAN Laerhoven, C. 1972. Lead uptake by, cettuce and oats as affected by lime nitrogen, and sources of lead. J. Environ. Qual. 1, 2: 169-171.

Linnman, L., Andersson, A., Nilsson, K. O., Lind, B, KJellström, T., \& Friberg, L. 1973. Cadmium uptake by wheat from sewage sludge used as a plant nutrient source. Arch. Environ. Health 27: 45-47.

Miller, J. E., Hassett, J. J. \& Koeppe, D. E. 1976. Uptake of cadmium by soybeans as influenced by soil cation exchange capacity, $\mathrm{pH}$ and available phosphorus. J. Environ. Qual. 5, 2: 157-160.

Sorteberg, A., 1974. The effect of some heavy metals on oats in a pot experiment with three different soil types. J. Scient. Agric. Soc. Finl. 46: 277-288.

Takijima, Y., Katsumi, F. \& Takezawa, K. 1973. Cadmium contamination of soils and rice plants caused by zink mining. II. Soil conditions of contaminated paddy fields which influence heaby metal contents of rice. Soil Sci. Plant Nutr. 19(3): 173-182.

Williams, C. H. \& David, D. J. 1976. The accumulation in soil of cadmium residues from phosphate fertilizers and their effect on the cadmium content of plants. Soil Sci. 121, 1: $86-93$.

Ms received July 13, 1978 .

SELOSTUS $\left.{ }^{1}\right)$

\section{Raskasmetallien vaikutuksista kauraan}

Asbjørn Sorteberg

Norjan Maatalouskorkeakoulu, 1432 As-NLH

Norjan Maatalouskorkeakoululla on vuosina 1973-76 tehty 4-vuotinen astiakoesarja, jossa on tutkittu maahan lisätyn kadmiumin, koboltin, lyijyn, elohopean ja nikkelin vaikutuksia kauran kasvuun ja raskasmetallien ottoon. Savi-, hieta- ja turvemaahan lisätyt raskasmetallimäärät olivat $0 \mathrm{mg}, 50 \mathrm{mg}$ ja $250 \mathrm{mg} 5$ maalitraa kohti. Koetekijänä oli lisäksi kalkitus. Vuosina 1974-76 tehtiin myös toinen koesarja, jossa lisätyt raskasmetallimäärät olivat paljon pienempiä: 0 , 0.5 ja $5 \mathrm{mg} /$ astia. Jälkimmäisessä kokeessa tutkittiin vain kadmiumia ja elohopeaa.

Maahan lisätty suuri raskasmetalliannos, $250 \mathrm{mg} /$ astia, alensi selvästi kaurasatoa. Lyijy muodosti kuitenkin poikkeuksen, sillä sen lisääminen ei vaikuttanut sadon määrään. Elohopean haitallinen vaikutus kaurasadon määrään loppui kolmantena vuonna. Myös nikkelin haittavaikutus pieneni vuosi vuodelta, mutta kadmiumin ja koboltin osalta vaikutuksen pienenemistä ei neljän vuoden kuluessa havaittu. Voimakas kalkitus, jolla maan pH-luku nostettiin välille $6-7$, eliminoi lähes täysin nikkelin haittavaikutuksen ja pienensi huomattavasti koboltin haittavaikutusta.

Kaurasadon kadmium-, nikkeli-, koboltti- ja elohopeapitoisuudet moninkertaistuivat lisättäessä näitä metalleja maahan $250 \mathrm{mg} / 5 \mathrm{l}$. Jo pieni annos kadmiumia, $0.5 \mathrm{mg} / 5 \mathrm{l}$, lisäsi selvästi sekä jyvä- että olkisadon kadmiumpitoisuuksia. $0.5-5 \mathrm{mg}$ elohopeaa 5 :een maalitraan lisättynä ei sen sijaan vielä selvästi kohottanut kaurasadon elohopeapitoisuutta. Ras- 
kasmetallipitoisuudet pienenivät vuosi vuodelta. Neljäntenä vuonna ei suurimmankaan elohopea-annoksen vaikutusta kaurasadon elohopeapitoisuuteen voitu enää todeta. Lyijyn lisääminen maahan aiheutti vain pienehköjä lyijypitoisuuksien kohoamisia kaurasadossa.

Keskimäärin $45-55 \%$ maahan lisätystä kadmiumista, nikkelistä ja koboltista oli analysoitavissa maanäytteistä ammoniumlaktaattiin uuttuvassa muodossa, kun maita oli kalkittu vain lievästi noin $\mathrm{pH}$ 5:een. Voimakkaan kalkituksen $(\mathrm{pH} 6-7)$ vaikutuksesta maahan lisätystä metallimäärästä oli $\mathrm{AL}$-menetelmällä analysoitavissa huomattavasti pienempiä määriä: kadmiumia 3-7\%, nikkeliä $16-20 \%$ ja kabolttia $22-24 \%$ AL-liukoiset raskasmetallipitoisuudet olivat korkeimpia turvemaassa ja alhaisimpia savimaassa.

1) Selostuksen laatinut P. Elonen. 